\title{
Leitura e escrita, direito e necessidade
}

\author{
Renato Beluche \\ Mestrado em ciências sociais pela Universidade Federal de São Carlos - UFSCar \\ E-mail: renatobeluche@gmail.com
}

CASTRILlÓn, Silvia. O direito de ler e de escrever. Tradução de Marcos Bagno. São Paulo: Pulo do Gato, 2011. 103 p.

Na obra $O$ direito de ler e de escrever, a bibliotecária e pesquisadora colombiana, Silvia Castrillón tece, por meio de cinco conferências empreendidas entre 2001 e 2004, uma reflexão sobre diferentes temas que perpassam a leitura e escrita na América Latina.

Castrillón participou da criação da Asociación Colombiana para el Libro Infantil y Juvenil, da Funda-lectura - Fundación para el Fomento de la Lectura, foi consultora de organismos como Unesco, OEA, Secab, Cerlac e ONU sobre bibliotecas públicas, promoção de leitura e escrita, além de dirigir a Asolectura (Asociación Colombiana de Lectura y Escritura).

Sua obra aborda variadas questões que permeiam o universo de quem, de modo direto ou indireto, trabalha com a problemática da leitura e escrita. A escola, local de confluência de práticas pedagógicas, lúdicas, de formação cidadã tem nos espaços reservados a leitura e escrita (a nomenclatura é variada: biblioteca, sala de leitura, cantinho de leitura entre outros) um ambiente privilegiado para equalizar todas essas funções. Nesse contexto, o livro torna-se uma ferramenta importante que nos leva a reflexão e a crítica dos programas de incentivo a leitura, da falta da relação desses com a escrita, dos índices de leitura, do papel do Estado e da sociedade civil, entre outros.

O primeiro capítulo, $O$ direito de ler, como o próprio título sugere, trata da leitura e escrita como direito de todos e compromisso de muitos. Destaca que os índices de leitura per capita não significam necessariamente democratização da leitura, significam apenas o aumento na compra de livros, nesse sentido seria necessário criar novos indicadores de gestão para não ficar, segundo suas palavras, contabilizando cadeiras ocupadas ou livros consultados.

Para a autora é necessário que as políticas de Estado elenquem como prioridade tanto a educação quanto a biblioteca reorientando as ações para essas duas instituições. É fundamental que a leitura e a escrita se tornem necessidade sentida por grandes setores da 
educação e instrumento para seu beneficio. Nesses termos a ideia da democratização não se refere apenas ao acesso a todos, mas se transforma em um instrumento de poder contra a exclusão.

No segundo capítulo, Mudar é difícil, mas possível: o desafio ético e político do bibliotecário, o foco está no papel ético e político do bibliotecário, principalmente, o público. Destaca que as funções da biblioteca não devem se restringir ao apoio a escola, lazer e acesso, mas lutar contra a exclusão, questionar, responder e fomentar a leitura, para formar sujeitos autônomos.

A leitura não deve ser encarada como entretenimento, mas como necessidade, deve ter uma relação com o projeto de vida dos indivíduos. Para a concretização desse processo é fundamental uma educação de qualidade e um profissional que, segundo a autora, seja um intelectual capaz de assumir um compromisso ético e político na sociedade. É necessário valorizar o status do bibliotecário, superar o estritamente técnico-profissional e reconhecer que esse trabalho permite a outros transcender e melhorar sua condição humana.

Leitura: educação e democracia, terceiro capítulo, tem como temática central os equívocos quanto as concepções de leitura. Embora exista o real aumento dos incentivos a leitura os avanços são poucos. O problema começa na própria concepção da leitura que os programas de incentivo engendram. Geralmente se dividem em três estratégias que muitas vezes são concomitantes e não excludentes: campanhas baseadas no lúdico, assistencialistas ou atreladas as necessidades de mercado. Quanto as primeiras, baseadas no lúdico, acabam por encarar a leitura como algo de que se possa prescindir, um luxo, com motes como: "ler é bonito", "ler é fácil", suas intenções são positivas, mas ingênuas, pois criam falsas expectativas e associam a leitura a uma ação inútil e descartável. Destaca que a proposta do livro como um bem cultural fácil e como entretenimento deixa-o em desvantagem com outros meios como, por exemplo, a televisão.

A penúltima conferência, A biblioteca cria cidadãos mais bem informados? Trata das tendências seguidas pelas bibliotecas públicas e das fontes de informação mais usados pelos indivíduos. Desde suas origens as bibliotecas públicas serviram (e servem até hoje) para dar suporte e orientação ao serviço acadêmico e escolar. Modelo esse que é predominante nos países pobres devido, principalmente, a falta de investimento em bibliotecas escolares. De surgimento posterior, o outro modelo de serviços mais inclinado para o lazer ou recreação é predominante nos países ricos. 
Destaca, Castrillón, que existem três grandes grupos de informação: o primeiro é a informação científica e técnica, o segundo são as informações na forma dos dados (usados de modo individual e utilitários - dessa informação ocupam-se bibliotecas públicas e outros centros de informação) e o terceiro são as notícias (de todos os gêneros - constitui o patrimônio das mídias). Os dois primeiros grupos são próprios das bibliotecas públicas e centro de informações que ainda não conseguiram se apropriar do terceiro. As informações veiculadas, principalmente pela televisão, geram demandas e expectativas na população, daí conclui-se a necessidade de planejar algum tipo de mediação como, por exemplo, por meio de debates de temas atuais que a mídia apresenta (ou oculta). Carol Kuhlthau (2009) também destaca esse compromisso com a leitura crítica quando discorre que a televisão é uma das fontes de informação mais difundidas e penetrantes (induz atitudes, fornece informação e lazer). As técnicas de avaliação e seleção aprendidas ao longo do programa da biblioteca podem ajudar a escolher, filtrar e fazer uma leitura crítica de sua programação. Os alunos devem aprender que os programas podem ser aprofundados com os materiais da biblioteca. A exibição de materiais vinculados aos programas de televisão acabam se tornando uma forma de despertar o interesse para outros materiais e que, portanto, a televisão não deve ser encarada como adversária, mas como uma aliada no processo pedagógico. Em verdade, o único aspecto que eles competem é na relação com o tempo disponível e os programas da biblioteca podem auxiliar na tomada de decisões.

Por fim, no último capítulo, A sociedade civil pede a palavra: políticas públicas de leitura e escrita e participação social, discorre principalmente sobre o tema central e título do livro, à saber, a leitura e a escrita como direitos. Para alterar a situação das bibliotecas como local de prestação de serviços precários é necessário tratar a leitura como um direito, como "práticas que ajudam as pessoas a construir sua individualidade, criar seu espaço no mundo e estabelecer relações com os demais" (93). Porém destaca a necessidade de participação da sociedade civil e da vinculação da leitura a questões de sobrevivência imediata. Destaca, por fim, a ausência da escrita nos programas. Se antes o monopólio da sabedoria estava centrado na leitura hoje, talvez, esteja na escrita. Dessa forma, a leitura sem escrita é apropriação parcial da cultura letrada.

O livro toca em pontos fundamentais para quem se interessa pelos mais variados aspectos que tangem a leitura e a escrita, principalmente para quem desenvolve trabalhos na área de mediação de leitura. A obra traz importantes reflexões que nos levam a questionar não 
só as políticas públicas e os índices sobre leitura, mas a nossa própria prática cotidiana de leitores ou mediadores culturais.

\section{Referencia}

KUHLTHAU, Carol. Como usar a biblioteca na escola: um programa de atividades para o ensino fundamental. Belo Horizonte: Autêntica, 2009. 